\title{
REDRAWING WHITMAN'S CIRCLE
}

\author{
CARMine SARRACINo
}

\section{I}

ON June 7, 1877, THREe YeArs AFTER EMERSON published Parnassus, his poetry anthology now noteworthy for its omission of Walt Whitman, Edward Carpenter wrote in a letter to John Burroughs: "The truth is, as it appears to me now, that Emerson is a purely 'literary' man. I never understood that before, and I believe no 'literary' mind can accept Whitman." What did it mean to Carpenter to "accept Whitman"? In a letter to Clara Barrus, J. W. Wallace, a Whitmanite in the "College" group in Lancashire, described Anne Gilchrist as an ideal reader of Walt Whitman. "The reading of the complete edition of 'Leaves of Grass,"” writes Wallace, "was to Mrs. Gilchrist an overwhelming revelationunprecedented and unlooked for. It opened up vistas within her soul of unimagined glory and significance, and cast a powerful beam of light upon the whole of humanity and the universe, which transfixed them before her eyes. . . . It appealed to every part of her nature-body and soul-with a voice at once individual and divine."2

Clearly, Mrs. Gilchrist's virtual conversion experience far exceeded the "purely literary," and represents, we shall see, the kind of acceptance Carpenter required. Critics, however, who generally confine their attention to the literary, have been repulsed by the quasi-religious response of the Whitmanites, or, as they've been called, "the Whitmaniacs." Bliss Perry's term, "the hot little prophets," has stuck as a label for Carpenter, Gilchrist, William Douglas O'Connor, Wallace, Richard Maurice Bucke, William Sloane Kennedy, Horace Traubel, and others in England and America. ${ }^{3}$ In this essay, I propose, however, to reconsider and reevaluate Whitman's loosely connected circle of disciples by closely examining, rather than dismissing out of hand, their transliterary ideals and their visionary sense of Walt Whitman's significance and importance.

One problem with such an analysis is that we have few cases that compare with the Whitmanites (Thomas Carlyle's disciples come to mind), and, consequently, virtually no literary or cultural context in which to examine the phenomenon of Whitman surrounded by his adoring "Whitmaniacs." The spectacle strikes us, prima facie, as ego-indul- 
gent, charlatanic, mindless-somewhat like, in our own time, New Agers surrounding a channeler. But not so in the East. For instance, the poetsaint is the center of a serious and distinguished literary tradition, and is, therefore, a culturally familiar and respected figure. One thinks of Valmiki (know as the adhi kavi, or "first poet," author of the ancient Ramayana, the single most well-known work of literature in the world), Nanak, Kabir, Mirabai, and Tulsidas, to name some of the most famous poet-saints. Hundreds and even thousands of years after their deaths, their poems are still memorized by school children, recited at weddings and at religious celebrations, and performed for a few rupees by wandering street singers in Delhi, in Calcutta, and even in the most remote villages. Surely these poets have satisfied Whitman's prime measure of a poet, articulated in the last line of the 1855 Preface, and then repeated and elaborated throughout his life and work, "The proof of a poet is that his country absorbs him as affectionately as he has absorbed it." Can we see Whitman himself as a misplaced member of the poetsaint tradition? Interestingly, many Indian readers have done so, almost from the first. ${ }^{4}$ To them, geographical boundaries have mattered less than the inherent characteristics of the poet-saint, which Whitman exhibits.

Before moving on to the characteristics of the poet-saint, let me first clear up what is almost surely misunderstood: to link Whitman with the Indian tradition of the poet-saint is not to use the word "saint" in the Western sense at all. In Western usage, the word "saint" suggests religious devotion, rejection of the world and of earthly pleasures, struggle against and suppression of the dark side of one's nature. No one who has read Whitman, especially the "Calamus" poems and "Children of Adam," could accept the notion of Walt Whitman as a "saint" in that sense. ${ }^{5}$ In the Indian sense of the word, however, "saint" derives from the Sanskrit sant, a form of the verb "to be." In this sense "saint" has nothing to do with conventional religious virtues at all. Rather the saint/ sant is one whose very being (apart from behavior, say, or accomplishments) is extraordinary-something, as I shall make clear later, Whitman's devotees repeatedly claimed for him.

In Vedic philosophy, pure being (sit-chit-ananda) underlies all mental activities and processes. Further, being is, in a sense, obscured by mental activity because our attention is directed toward the content of the active mind and away from the fundamental state of being. Whitman himself claimed that he had the gift for experiencing pure being by stopping thoughts at will and making his brain "negative." ${ }^{\prime 6} \mathrm{He}$ shares this experience with the Upanishadic seers of India in general, and more specifically, with the poet-saints such as Valmiki, Kabir, and Mirabai. Critics who are aware of this Eastern tradition of the poetsaint usually view the phenomenon of the gathering of the circle of devo- 
tees as culturally determined. To simplify, it happens because it has always happened so in that particular culture. An alternative view which encompasses the Whitman phenomenon is that devotees gather because of the natural interpersonal dynamics of consciousness. As Emerson says in "Self Reliance," "Inasmuch as the soul is present there will be power. . . . Who has more obedience [to soul] than I masters me, though he should not raise his finger. Round him I must revolve by the gravitation of spirits" [italics mine]. ${ }^{7}$ Interestingly, the image of disciples revolving like planets around the fixed, central brilliance of the seer (like the ring of dancers around Frost's secret that "sits in the middle and knows") is found throughout Vedic literature. Perhaps, then, disciples gather round a poet-saint not because of mere cultural convention, but rather because of the inherent mechanics of consciousness, Emerson's "gravitation of spirits." 8

The defining characteristic of the poet-saint is an overwhelming and transforming experience of expanded awareness, which in itself and in all its transformative expressions becomes a main topic of the poetsaint's work. Examples from the poet-saints of India and Whitman are innumerable, but, to give a concrete example, consider this poem from Kabir, reminiscent of Whitman's "When I Heard at the Close of the Day":

When my friend is away from me, I am depressed;

nothing in daylight delights me,

sleep at night gives no rest,

who can I tell about this?

The night is dark, and long . . . hours go by ...

because I am alone, I sit up suddenly,

fear goes through me....

Kabir says: Listen my friend, there is one thing in the world that satisfies, and that is a meeting with the Guest. ${ }^{9}$

The "meeting with the Guest" is Kabir's way of describing his mystical experiences of transcendence, sometimes rendered, as in Whitman, in sexual terms. Another of Kabir's poems, for instance, reads:

Shall I flail with words, when love has made the space inside me full of light?

I know the diamond is wrapped in this cloth, so why should I open it all the time and look?

When the pan was empty it flew up; now that it's full, why bother weighing it?

The swan has flown to the mountain lake!

Why bother with ditches and holes anymore?

The Holy One lives inside you-

why open your other eyes at all? 
Kabir will tell you the truth: Listen brother!

The Guest, who makes my eyes so bright, has made love with me. ${ }^{10}$

Turning to Whitman now, the famous Section 5 of "Song of Myself" is a good example of the transforming mystical experience, described erotically. It reads in part:

I mind how we lay such a transparent summer morning,

How you settled your head athwart my hips and gently turn'd over upon me,

And parted the shirt from my bosom bone, and plunged your tongue to my

bare-stript heart,

And reach'd till you felt my beard, and reach'd till you held my feet.

Those who read Section 5 as a description of a sexual experience, whether homosexual or heterosexual, are stymied by their own insistence on literality. Literally, the passage can only describe amorous contortionists. Eastern tradition, however, offers another possibility. O. K. Nambiar, an Indian critic who writes about Whitman as part of the yogic tradition, considers Whitman's experience here to be a classic example of "kundalini." In the traditions of tantric yoga, kundalini is a powerful, subtle energy located at the base of the spine. It is represented symbolically as a coiled, sleeping serpent. When it awakens, it moves up the spine, spreading ecstasy as it uncoils. Bliss is concentrated at key energy centers, called chakras, located, for example, at the groin, at the throat, and at the heart - all of which figure in Whitman's experience. Once again, then, Whitman manifests the "poet-saint," and others who have had weaker versions of the same experience are drawn to him as a "master."

In the introduction to her collaborative translation, with Shukdev Singh, of a central work of Kabir's, Linda Hess tells a personal poignant story, one that Edward Carpenter would understand, about her awakening to the limitations of the literary. ("Gayabanandji" in what follows is a Kabir devotee in India.)

I was at one of the Kabir Panth camps talking politely with the gurus and officials. Gayabanandji came into the small tent and sat down. I had asked for help on an obscure line in a poem, and two pandit-types were going at it - the usual tug-of-war between ignorance and commentaries, punctuated by stabs at Sanskrit etymology and quotations from the Bhagavad Gita. After listening a few minutes he said, "Stop your controversies. Nothing will come of that." Then he explained his own understanding. $\mathrm{He}$ talked about the animal symbolism of the poem. There was a bullock who was cast as a patwari, a rural accountant who keeps records of land, revenue, harvest, and so on. A bull is a fool, said Gayabanandji, he is stupid. The patwari writes and writes about what other people have harvested, but gets nothing for himself. 
At some point I realized he was talking about me. My hand stopped over the notebook. I looked up and saw him looking at me. ...

From the moment I got the message that I was a patwari, I was ashamed. Could I ask more questions? And take more notes? And carry on with my distracted life? I remember that earlier someone had tossed off the comment that the motive for doing translations was to make a name for oneself.

I told Gayabanandji I wanted to ask him a personal question. Should I be trying to do this work? He laughed. "Oh the work is very good."

"The work is good," I said, "but is the worker?"

He said, "Look, the work is good for you because it makes you sit with saints and sadhus. You may learn something from that." 11

In "Poet of the Cosmos," a chapter on Whitman in Accepting the Universe, Burroughs echoes Gayabanandji regarding contact with a master's - in this case Whitman's - spirit: "Let me say that whatever else 'Leaves of Grass' may be, it is not poetry as the world uses that term. It is an inspired utterance, but it does not fall under any of the usual classifications of poetry. Lovers of Whitman no more go to him for poetry than they go to the ocean for the pretty shells and pebbles on the beach. They go to him for contact with his spirit; to be braced and refreshed by his attitude toward life and the universe; for his robust faith, his world-wide sympathies, for the breadth of his outlook, and the wisdom of his utterances." 12 And Whitman's disciples certainly regarded him with the reverence- qualitatively different from literary admirationwhich is traditionally associated with the poet-saints of India, such as Kabir. Burroughs, Bucke, Gilchrist, and even the semi-literate Peter Doyle found in Whitman an ideal of human development, of evolution of consciousness, so lofty as to inspire in them devotion and even selfsacrifice. Consider Anne Gilchrist's letter dated December 4, 1875, for example. Gilchrist urged Whitman, who was weakened from his stroke in 1873, not to give up, if only for the sake of "those that so tenderly, passionately love you-who would give their lives for you."13

Before he met Walt Whitman, Burroughs had been looking for a "master," for the man who is as we ourselves are, but more so: more developed, more evolved. That man, or "master," leads us forward to our fuller selves by his teachings, by his mentoring, and, most of all, by the example of his own life. ${ }^{14}$ Four years before meeting Whitman, Burroughs wrote in his notebooks, "Hence, men become leaders only by greater power of expression; by affording a free passage to that which is obstructed in others. ... [T] hat man is our hero who is more ourselves than we are; who beats us at our own game; who surpasses us in our own direction." ${ }^{15}$ After meeting Whitman, here is one of Burroughs's 
descriptions of him: "Notwithstanding the beauty and expressiveness of his eyes, I occasionally see something in them as he bends them upon me, that almost makes me draw back. I cannot explain it-whether it is more, or less, than human. It is as if the Earth looked at me-devout, yearning, relentless, immodest, unhuman. If the impersonal elements and forces were concentrated in an eye, that would be it." 16

Bucke's description of Whitman similarly glimpses the "master," the transcendental spirit of nature expressed in individual form: "His ruddy face, his flowing, almost white, hair and beard, his spotless linen, his plain, fresh looking gray garments, exhaled an impalpable odor of purity. Almost the dominant initial feeling was: here is a man who is absolutely clean and sweet - and with that came upon me an impression of the man's simple majesty, such as might be produced by an immense handsome tree, or a large, magnificent animal." 17 The impression of extraordinary purity Whitman conveyed to his devotees was noted also by Peter Doyle: "Woman in that sense never came into his head. Walt was too clean. No trace of the dissipation in him." ${ }^{18}$ And, like the other devotees, Doyle too saw in Whitman an ideal man, an example to emulate, "When I am in trouble - in a crisis-I ask myself 'What would Walt have done under these circumstances?' And whatever I decide Walt would have done, that I do."19

In our critical consideration and appraisal of Whitman strictly as a nineteenth century poet, we altogether misunderstand the phenomenon of the disciples who gathered around him. We expect traditional literary interest in Walt Whitman from these devotees whose actual attraction to him went far beyond the literary, and who even openly scorned the "merely" literary. In his journal on October 1, 1892, for instance, Burroughs advises (much as Gayabanandji advised Linda Hess regarding the medieval Bengali poet-saint Kabir), "If we come to Whitman in a critical frame of mind merely, in a frame of mind begotten by books ..., both critic and subject will fare poorly. Because in Walt Whitman the professional poet is not uppermost." 20

Most modern critics have regarded Whitman's prophetic voice (to which his devotees were keenly attuned) as a creative and aesthetic lapse. As Burroughs predicted, ". . . both critic and subject will fare poorly" [italics mine]. In The Lunar Light of Walt Whitman, for instance, Wynn Thomas argues that Whitman's work never droops so low as when it rises above "mere" poetry. From a poetic standpoint, Thomas is certainly right. But to the disciples, there was more going on than poetic virtuosity. One wonders, indeed, whether they would have been so compellingly drawn to Whitman if he remained always perfectly on key, if he were the unfailing craftsman. Whitman promised, after all, in the first section of "Song of Myself," that he, the inspired bard, would permit the "original energy" of Nature to speak through him, "for good or 
bad." "For good or bad" has several possible meanings here. It could refer to Whitman's commitment to trust Nature, which, the poet is aware, might turn out to be a good idea, or perhaps a bad one. The lines are not found in the 1855 edition, and appeared first in 1860, by which time Whitman had empirical evidence of the problematic nature of his endeavor. "For good or bad" could also refer to the content of the uncensored, unmediated poetry to come, which might (who knows?) turn out to be a poetry of evil as much as of good-an idea that recurs in Whitman with similar implacability. Or the phrase might refer to the aesthetic quality of the poetry itself. Most likely, all these meanings apply in a rich ambiguity, and indicate Whitman's awareness that, extensive revising notwithstanding, his work would surely suffer in aesthetic purity and in palatability by his "hazarding" a commitment to intoxicated, visionary language. But, so be it.

What is more, the very unevenness of his songs, the lapses, the occasional awkwardness, the casualness bordering on clumsiness, would communicate through a kind of body-language of the poetic line the distinct, eccentric personality who was singing these songs (we recall the akimbo, hips-aslant, head-cocked portrait of the poet in the 1855 edition), and would communicate as well the singer's half-cracked resolution to launch out with no pre-set destination, to discover personal and even cosmic truths by chanting, by letting go and swinging through pure silence on the vines of primordial sound. The disciples, relishing this "non-professional poetry," were not fazed that critics found fault. As much as the poetry itself, they valued the man, the consciousness, embodied in the poetry. Here was a man, a master, to sit near.

The opposing assessments of Whitman's prophetic voice, then, constitute a kind of Mexican standoff in Whitman studies. The two perspectives, that of the detached critic versus that of the attached devotee, proceed from sets of values entirely different from each other, and may be ultimately non-compromisable. Carpenter's epiphany regarding Emerson (cited at the beginning of this article) could be paraphrased "I see it now-he is one of them. I thought he was one of us." Emerson's deliberate snub of Whitman in Parnassus, can, in the same way, be seen as a signal to the Boston clique of poets and critics that he, Emerson, stands squarely with the men of letters - and not with the lunatic fringe. It is not sensible to try to reconcile the differences between the two groups - that is, between those who regard Whitman as a prophet, and those who, on aesthetic grounds (and probably on more general philosophic grounds as well) regard Whitman's prophetic voice as a poetic weakness. It is also a mistake, and still quite common, to dismiss the devotees with prejudicial condescension. Despite the disparaging names, however, the devotees were far from mindless. Rather, they consisted of an avant garde psychiatrist, an accomplished naturalist, and an assortment of writers, scholars, and critics in England and America. 
Beyond their reverence for Whitman, however, we do not find among the devotees defining common elements. That is, they do not all see Whitman as a herald of manly love, for instance. Nor do all of them see him as a founder of a new religion, or as a political radical, or as a feminist, or as a mystic, or as a potential ideal lover. Rather, various of these elements recur among the disciples in altering combinations. To put it another way, in this family of devotees, there is nothing like the common element of the Hapsburg lip. Rather, some have the element of the distinctive walk, some the element of the lip, some the temperament. Common elements "overlap and crisscross" among members, as Wittgenstein said of "family resemblances" in Philosophical Investigations.

I will focus here on just two of the important elements that the devotees found in Whitman. The first is that of Walt Whitman as the founder of a new religion, a religion based not on dogmatic belief but rather on the evolution of the human consciousness. Secondly, I will discuss the related vision of Whitman as the harbinger of an ideal relationship among males, known as manly love, or in the phrenological term he favored, "adhesiveness."

\section{III}

Not only did Whitman undergo "mystical experiences" of pure being, pure consciousness, but, further, he wanted to identify such experiences categorically. Like William James after him, Whitman recognized a rare but potentially universal transformative human experience. We could call this category of human experience "religious," but Whitman shied away from the word "religious" as misleading. "The people," he wrote in his 1872 Preface, "especially the young men and women of America, must begin to learn that religion (like poetry,) is something far, far different from what they supposed." 21

In his 1876 Preface, Whitman refers to this new religion as "a more splendid theology." The defining character of this new religion would be its rootedness in direct, personal experience rather than in notional understandings and beliefs. In fact, Whitman looks to three Christian models of true religious spirit, all of whom are distinctly non-dogmatic, unconventional, emotional rather than dryly intellectual, "mystical and radical": George Fox, Father Taylor, and Elias Hicks (PW, 2:638). All were examples of the movement towards a "new theology," or, as Whitman sometimes preferred, "a more splendid theology" ( $P W, 2: 462$ and 473).

In George Fox, as with the other two, Whitman found an emphasis on inwardness, on the mystical experience of an inner light. Whitman quotes Fox: "II come,' he said, 'to direct people to the spirit that gave forth the Scriptures"' [italics mine] (PW, 2:650). The quotation calls to 
mind the seventh section of "Passage to India" in which Whitman identifies transcendence ("primal thought") as the source of "budding bibles."

In Father Taylor, "the sailor's preacher," Whitman found a man of great spiritual power who was nonetheless unstudied and unconventional. He spoke from a pulpit that rose "ten or twelve feet high . . . back'd by a significant mural painting, in oil ... of a stormy sea, the waves high-rolling, and amid them an old-style ship, all bent over, driving through the gale, and in great peril - a vivid and effectual piece of limning, not meant for criticism of artists . . . but for its effect upon the congregation, and what it would convey to them" ( $P W, 2: 550)$. But as Whitman noted, Father Taylor's great power derived from the fact that he was an "essentially perfect orator-one who satisfied those depths of the emotional nature that in most cases go through life untouch'd, unfed" $(P W, 2: 549)$. When listening to Taylor's sermons, filled with "allusions to ships and the ocean and the sailor's lives," Whitman was "affected . . . to tears" ( $P W, 2: 550)$.

Elias Hicks, whose own theology was one of inner experience, also had the gift of natural eloquence that could move listeners to tears. And for Whitman, tears were the sign that the soul itself had been stirred, that the spirit had been awakened. This "unstudied oratory" of Hicks and Taylor was not "argumentative or intellectual" but it was a "magnetic stream of natural eloquence before which all minds and natures, all emotions . . . yielded entirely" ( $P W, 2: 638-639)$. It was in this yielding to an inner experience, to a "noiseless secret ecstasy and an unremitted aspiration" that Whitman believed one found the "true Christian religion" that would flower "in purity, in a good practical life, in charity to the poor and toleration to all" (PW, 2:638n). Whitman uses almost the same language in Democratic Vistas when he describes a religion of expanded awareness and transcendence: "Bibles may convey, and priests expound, but it is exclusively for the noiseless operation of one's isolated Self, to enter the pure ether of veneration, reach the divine levels, and commune with the unutterable" (PW, 2:399). This experience of transcendence, a fourth major state of consciousness which is a main subject of Vedic literature, was for Whitman-and his devotees-the heart of religious mystical experience.

Of Whitman's devotees, Carpenter, Burroughs, and Bucke clearly recounted such mystical experiences. In late March or early April 1873, for instance, Bucke had an overwhelming experience of what he termed "cosmic consciousness." He first met Whitman on October 18, 1877, and the experience of Whitman's presence somehow rekindled that earlier mystical experience, so that when he parted from Whitman he felt slightly intoxicated and exalted-as he put it, "in a clearly marked degree" for at least six weeks - and the experience never faded completely. ${ }^{22}$ 
On October 24, 1877, Bucke wrote to Harry Buxton Forman, "I may say that I experienced what I have heard so much about the extraordinary magnetism of his presence-I not only felt deeply in an indescribable way toward him-but I think that that short interview has altered the attitude of my moral nature to everything" (Bucke, 46). This experience of directly imparting a higher state of awareness to the devotee is called darshan in the poet-saint tradition, and not Bucke alone but in fact most of the devotees made such claims for Whitman. William Sloane Kennedy, for example, said, "I never knew a person to meet him for the first time who did not come under his spell; most people going away in such a curious state of exaltation and excitement as to produce a partial wakefulness, the general feeling not wearing off for a fortnight." 23

Also, most of the disciples at least dabbled in the newly translated religious texts of ancient India and China, which offer a vision of the development of consciousness to its fully expanded state, called "enlightenment" or "cosmic consciousness." Carpenter, for instance, listed parallels between "Song of Myself" and the Upanishads. Bucke, however, was the most learned in "Oriental philosophy." The Light of Asia by Sir Edwin Arnold (London, 1879) inspired him to make his way through fifty volumes of Max Muller's classic The Sacred Books of the East (Oxford, 1879-1910). Perhaps because his personal mystical experience was so thoroughly bolstered by keen intellectual understanding, Bucke was the most fanatically devoted to Whitman's "more splendid theology." On November 9, 1888, he wrote to Horace Traubel, “ . . . it is my dream to devote the rest of my life (not many years perhaps, but still a few) to the study and promulgation of the new religion. . . " "24 To Whitman, he wrote on June 3,1889, that in twenty-five or in at most fifty years, he, Bucke, would "not be surprised to see my highest claims for you (for making which I have been counted a lunatic) broadly and even generally allowed" (Bucke, 126).

As Whitman became more debilitated and ill, Bucke became almost panic-stricken at the realization that his scientific work of explicating cosmic consciousness could never be completed absent its most perfect specimen. On March 20, less than a week before Whitman's death, he mailed Traubel a questionnaire probing the specifics of Whitman's evolution which Whitman, who even in health preferred "hints" at most and aslant allusions, never answered. About a week earlier on March 14, the frantic Bucke had written to Traubel: "Do you think Whitman would tell you anything about his own experience of cosmic consciousness? Would you try him some day . . . ? Do not say that I asked you ... try to get as much from him/ask him/something about it. . . . Did a luminous haze accompany the onset of cosmic consciousness?" (Bucke, 179). Later in the same letter: ". . . but I fear he will say nothing. If I had known as much a few years ago [about cosmic consciousness] as I do now I would have got some valuable statements 
from him but now I fear it is too late." Indeed it was too late. Twelve days after Bucke's writing, Whitman was gone from the world, leaving Bucke's questions unanswered. Bucke's efforts to dissect, to chart, to formalize and rigidify in a scientific framework the most expansive, fluid, and indefinite aspect of human potential, "cosmic consciousness," must have struck Whitman as even more misguided than the learn'd astronomer's dissertation on the cosmos. Whitman responded to Bucke as the astronomer by "gliding out" into the "mystical moist night-air" in perfect silence.

To the devotees, then, Walt Whitman was more than a literary figure. He was an ideal man, and even for some, a messiah-like evolutionary prototype-not a poet "merely," but a poet-seer, a poet-saint. To see him so strikes us, in our hard-bitten and cynical times, as stunningly naive, even delusional, as our names for the devotees ("hot little prophets") attest.

In Whitman and Burroughs: Comrades, however, Clara Barrus discusses the nineteenth-century convention of "manly love," which may shed some light on the phenomenon of so many men either literally or figuratively gathering around the elder Whitman. Young men, especially idealistic, literary young men, commonly "fell in love" with one another in patterns that mimicked traditional heterosexual romantic love. These affairs, whether they represented repressed homosexuality or not, were highly idealized, even invoking the psyche-epipsyche ideal of Plato, as in this excerpt from a May 1, 1862, letter from E. M. Allen to John Burroughs: "If you were here now I should be happy, for you are my twin-spirit. We are like two lovers, are we not? Do you remember how we used to lie by the brook in the twilight? You ought to be a woman, John, or I." ${ }^{25}$ And later in the same letter: "I cannot help thinking of you when I feel the dreamy influence of spring, and long to be with you."

Everyone familiar with Whitman's correspondence with Peter Doyle knows the similarly affectionate, intimate tone of the letters they exchanged. ${ }^{26}$ In those letters, however, Whitman describes his intimacy with even other workmen. In a letter of September 10, 1869, “. . . some (pilots) when we meet we kiss each other (I am an exception to all their customs with others). . . " 27

In another letter, John Burroughs creates a portrait of "Richard" (Myron B. Benton) so idealized that it is one with his later descriptions of Whitman: "In the twilight 'Richard' and I made our bed on a gentle slope nearly overshadowed by a huge pine, where the moss was peculiarly thick and soft, and fell into one of our discursive and easy going talks - the sport and the play of the mind. . . 'Richard' rare old 'Richard!' What depths there are in thee, and what heights! What quaintness, what subtlety, what clearness of vision, what Norseman sturdiness and vigor." ${ }^{28}$ Burroughs later mentions Whitman to Benton in a letter that calls to mind Whitman's "When I Heard at the Close of the Day." 
Burroughs says, "I have been much with Walt. Have even slept with him. I love him very much." 29

To contemporary readers, the words and actions of Burroughs et alia will seem unquestionably homosexual. There is, however, no biographical evidence of homosexuality in the life of John Burroughs. We might, then, presume that these men were repressed homosexuals, but we must be careful even here to avoid the cultural arrogance of imposing our own perspectives on these men who, although they did not live so long ago, were nevertheless fundamentally different from us in some of their values, ${ }^{30}$ and in their sense of what was even sexually possible for males. The term "homosexual," for instance, had not yet been coined, and the idea of men desiring sex with other men was regarded (when it was regarded in public discourse at all) as a human pathology so bizarre and so rare as to hardly warrant the attention of normal males. ${ }^{31}$

The "Calamus" poems too, whether they are homosexual or not, often describe a manly love which mirrors the behaviors and conventions of heterosexual love. The fifth version of "Whoever You Are Holding Me Now in Hand," for instance, links the comrade with the "new husband" and describes an encounter on a "high hill" that recalls the fifth section of "Song of Myself." Also, "When I Heard at the Close of the Day," "We Two Boys Together Clinging," "Sometimes with One I Love," and "Among the Multitude," invoke the psyche-epipsyche ideal of ardent devotion to the one true lover. The devotees' adoration of Whitman is, then, of a piece with this convention of idealizing and romanticizing the male friend. Further, in the case of Whitman as the "male friend," we have devotion to someone who, in his own poetry, champions and amplifies the value of manly love itself.

Even more, the figure of Whitman, sitting like the secret in the middle of a ring of devotees, casts in a positive, compelling light the problematic inevitability of the ideal male grown old. Walt Whitman, the "rough" who could no longer sing his superabundant good health and energy, becomes now Walt Whitman the sage, the poet-seer, the herald of a race of "splendid and savage old men."

Elizabethtown College

\section{NOTES}

1 Clara Barrus, Whitman and Burroughs: Comrades (New York: Houghton Mifflin, 1931), 142.

2 Barrus, 154.

3 The Principle of Life, A New Concept of Reality based on Walt Whitman's "Leaves of Grass" by Philip Akers (New York: Vantage, 1992) regards Whitman's work as (to quote an advertisement blurb) "the greatest of all bibles-a bible fit for the coming 
millennia," and so even in contemporary times carries on the mission of Whitman's original devotees, but the book stands virtually alone in this enterprise.

4 Of course the first to note an affinity between Whitman's work and Eastern literature were Westerners. In their well-known meeting in 1856, Thoreau observed that Whitman's poetry was "wonderfully like the Orientals." Carpenter noted parallel verses from the Upanishads and Leaves of Grass. But it was V. K. Chari, an Indian by birth, who first offered a systematic, comprehensive analysis of Whitman's work in terms of Vedanta philosophy. Chari, who is presently on faculty at Carleton College in Canada, has been thoroughly grounded in Western modalities of research and scholarship. $\mathrm{O}$. $\mathrm{K}$. Nambiar, the author of Walt Whitman and Yoga (Bangalore: Jevan Publications, 1966), on the other hand, is an Indian critic who may be less palatable to Western scholars, but his joyous sense of Whitman as a kindred spirit-a displaced kundalini yogi, actually-typifies the kind of "familial" love of Whitman that I have encountered when lecturing on Whitman in India, Nepal, and Sri Lanka in the course of two Fulbrights. So widespread is the love of Whitman in India (far surpassing that for any other American writers) and so immediate the sense of kinship, that in the 1960s the Indian government, with a UNESCO grant, began an ambitious project to translate Leaves of Grass into the eighteen major languages of the country. Nambiar, better than anyone else readily available to Western readers, imparts a sense of why such a project would come about.

5 Whitman himself disdained the word. Presenting his vision of a new religion in his 1876 Preface, Whitman wrote: "[Religion] is, indeed, too important to the power and perplexity of the New World to be consign'd any longer to the churches, old or new, Catholic or Protestant-Saint this, or Saint that. It must be consign'd henceforth to democracy en masse, and to literature. It must enter into the poems of the nations. It must make the nation."

6 In an earlier article, I have explored this matter of being at some length, proposing that Whitman spontaneously experienced an extraordinary state of consciousness known as samadhi in Vedic literature (see "Figures of Transcendence in Whitman's Poetry," Walt Whitman Quarterly Review 5 (Summer 1987), 1-11.

7 Selections from Ralph Waldo Emerson, ed. Stephen E. Whicher (Boston: Houghton Mifflin, 1957), 158-159.

8 "Cultural convention" can never be a completely satisfying explanation of patterns of behavior, literary or otherwise, because the notion fails to deal with inception, with initial invention. To make an analogy, we can claim that poets write sonnets because they live in a culture with a tradition of sonnet writing. But, as William Stafford has observed in Writing the Australian Crawl, how did the first sonnet, then, come to be written? Perhaps the sonnet form itself, in its tensions and resolutions, is in a sense imaginatively latent in the structure of human consciousness, or alternatively, in the structure of human experience - in any case, "tradition" cannot, for the first sonnet, be the answer.

9 Kabir, the fish in the sea is not thirsty, versions by Robert Bly (San Francisco: Rainbow Bridge, 1971), 1.

10 Kabir, 7.

11 Kabir, The Bijak of Kabir, trans. Linda Hess and Shukdev Singh (San Francisco: North Point Press, 1983), 36-37.

12 John Burroughs, Accepting the Universe (New York: Wm. H. Wise, 1924), 317. 
13 The Letters of Anne Gilchrist and Walt Whitman, ed. Thomas Harned (New York: Doubleday, 1918), 56.

14 Many of the disciples, such as Harry Bryan Binns, addressed Whitman as "Master" in letters to him. ("Master" is, of course, the traditional term in India for one's spiritual teacher.) Even after Whitman's death, Burroughs continued to address him so, in a journal entry addressed to Whitman dated April 6, 1892, which begins "Again dear Master. ... "

15 Barrus, Introduction, xix.

16 Barrus, 15.

17 Calamus: Letters to Peter Doyle, ed. R. M. Bucke (Boston: Laurens Maynard, 1893), 11. Edward Carpenter in Days with Walt Whitman (London: George Allen, 1906), 126 , describes Whitman's poetry in terms identical with the personal descriptions of Bucke and Burroughs: "Something greater than the moral speaks to us in them, some voice blended of ages and ages and vistas of human experience. Something more even than human; for Nature, the prairies and the lakes, the ocean and the forest by some hidden magic became vocal in them."

18 Calamus: Letters to Peter Doyle, 25.

19 Calamus, 29.

20 Barrus, 315.

21 Prose Works 1892, ed. Floyd Stovall (New York: New York University Press, 1964), 2:462-463. Hereafter abbreviated $P W$.

22 See R. M. Bucke, Medical Mystic, ed. Artem Lozynsky (Detroit: Wayne State University Press, 1977). Hereafter referred to as "Bucke."

23 William Sloane Kennedy, Reminiscences of Walt Whitman (London: Alexander Gardner, 1896).

24 Bucke, 114.

25 Barrus, $\mathrm{xx}$.

26 In an earlier article, I explored Whitman's relationship with Doyle in terms of the ideals of "manly love." For a discussion of "adhesiveness" and the possible sexual tensions between the poet and Peter Doyle, see "Dyspeptic Amour, Petty Adhesiveness and Whitman's Ideal of Personal Relations," Walt Whitman Quarterly Review 8 (Fall 1990), 86-89.

\section{Calamus, 58.}

28 Barrus, xxi.

29 Barrus, 13.

30 In the context of the Civil War, Gerald F. Linderman's Embattled Courage: The Experience of Combat in the American Civil War (New York: Macmillan, 1987) makes clear just how different from us these nineteenth century men were in some of their understandings and values. For example, so important was honor to these men, especially in the first two years of the war, that when southern General John Bell Hood realized that enemy troops were unaware of the Confederate presence, he ordered a major to lob a few shells over their heads so as to alert them. At the end of the war, a 
Union officer apologized to Confederate cavalry officer Wade Hampton because at the battle of Gettysburg, he had tried to saber Hampton from behind. So, what might seem to us, from our own perspective of war as "anything goes," to be opportunities, even lucky breaks - unquestionably so-struck these nineteenth century men as unacceptable, even shameful.

31 See Michael Lynch's "'Here is Adhesiveness': From Friendship to Homosexuality," Victorian Studies 29 (Autumn 1985), 67-96, for a discussion of the creation of a public homosexual identity and the development of a vocabulary of homosexuality. 